\title{
ISOLATION AND CHARACTERIZATION OF PEPTIDES FROM BLOOD SERUM OF PATIENTS WITH MULTIPLE SCLEROSIS
}

\author{
S. Myronovskij', N. Negrych ${ }^{2}$, T. Nehrych', M. Starykovych ${ }^{1}$, V. Tkachenko', \\ V. Yukalo ${ }^{3}$, L. Storozh ${ }^{3}$, O. Nemchenko', G. Lavryk', R. Stoika ${ }^{1}$, Y. Kit ${ }^{\prime *}$ \\ 1 Institute of Cell Biology, NAS of Ukraine, 14/16, Drahomanov St., Lviv 79005, Ukraine \\ ${ }^{2}$ Danylo Halytsky Lviv National Medical University, 69, Pekarska St., Lviv 79010, Ukraine \\ ${ }^{3}$ Ivan Puluj Ternopil National Technical University, 56, Ruska St., Ternopil 46001, Ukraine \\ *e-mail: kit@cellbiol.Iviv.ua
}

In order to find novel molecular markers of multiple sclerosis we developed a scheme of oligopeptides' isolation including their extraction from blood serum with $10 \%$ trichloroacetic acid, followed by precipitation of soluble substances with acetone in ratio 6:1. Oligopeptides were dissolved in water and their characteristics was determined by gel filtration under HPLC conditions and thin layer chromatography. Obtained data have shown that blood serum of MS patients contains two oligopolypeptides with average molecular masses of 300-500 Da. We also studied biological activity of TCA-soluble peptides toward some eukaryotic and prokaryotic cells in comparison with phosphopeptides isolated from casein hydrolysates. It was found that TCA-soluble peptides are capable of effective inhibiting HeLa cells' proliferation, while their inhibitory effect was expressed toward Jurkat T-cells and was not detectable toward U373 cells. The casein's phosphopeptides were capable to stimulate proliferation of Jurkat cells and effectively inhibited growth of cells. Neither antibacterial, nor antifungal activities of these oligopeptides were detected.

Keywords: oligopeptides, blood serum, bovine casein, multiple sclerosis, tumor cells, microbial cells.

MS, or "disseminated sclerosis", is an inflammatory disease at which the myelin sheaths around axons of brain and spinal cord are damaged, leading to demyelination and scarring, and, as a result, to a wide range of signs and symptoms [11]. MS is referred of autoimmune character because of cellular and humoral immune reactions towards brain tissue self-antigens, basically to myelin basic protein (MBP) that is the main characteristics of this disease [4, 7]. The main feature of patients with MS is the formation of inflammatory sites in brain tissue, accompanied by an increase in the proteolytic activity followed by destruction of MBP and subsequent demyelination of axons. This activity should be accompanied by elevation of the level of different peptides in the cerebrospinal fluid. There are data showing a rise in permeability of blood-brain barrier (BBB)

ISSN 1996-4536 (print) • ISSN 2311-0783 (on-line) • Біологічні Студії / Studia Biologica • 2015 • Том 9/№2 • С. 51-58 
in the MS patients $[3,10]$. We believe that such peptides might penetrate in blood from CSF where they can be detected, isolated and studied. Here we demonstrate the results of determination, isolation and characterization of low-molecular weight oligopeptides from blood serum of MS patients and of study of their biological activity toward tumor and microbial cells.

\section{MATERIALS AND METHODS}

In total 61 female and male patients of 20-50 years old with a proved diagnosis of multiple sclerosis according to the McDonald diagnostic criteria for MS (2010) were studied. A documented consent was obtained from all patients, that was approved by the Review Board of the Danylo Halytsky Lviv National Medical University, in accordance with the regulations of the Ministry of Health of Ukraine.

Isolation of peptides from blood serum. To isolate peptides (volume $1 \mathrm{ml}$ ), TCA was added to blood serum to obtaine $10 \%$ final concentration. After 30 min incubation at $4{ }^{\circ} \mathrm{C}$, solution was centrifuged at $10000 \mathrm{~g}$ for $15 \mathrm{~min}$, and the supernatant containing TCAsoluble compounds was mixed with acetone in ratio 1:6 as well as incubated for 4 days at $4{ }^{\circ} \mathrm{C}$. The precipitated substance was obtained by centrifugation at $10000 \mathrm{~g}$ for $10 \mathrm{~min}$. The pellet was dissolved in distilled water. Oligopeptides were concentrated by ultrafiltration on Amicon 30 filter (Amicon, USA) and its amount was measured using NanoDrop ND1000 (NanoDrop Technologies, USA) at $280 \mathrm{~nm}$. The solution was stored at $-20^{\circ} \mathrm{C}$.

Separation of TCA-extracted peptides. The TCA-soluble fractions of blood serum of MS patients were separated by high performance liquid chromatography (HPLC) on Bio-Sil SEC 250 (Bio-Rad) column in PBS pH 6.8 with a flow rate of $1 \mathrm{ml} / \mathrm{min}$ using Perkin Elmer Series 200 device. Proteins and peptides were detected by their absorption at $280 \mathrm{~nm}$. To identify obtained compounds SDS-electrophoresis in $12 \%$ PAG followed by Coomassie G gel staining [6] and thin-layer chromatography on silicagel plates in the acetic acid:n-butanol:water solution in ratio of 1:4:1 with ninhydrin staining [5] were used.

Biological activity of TCA-extracted peptides. The biological activity of purified peptides toward eukaryotic and prokaryotic cells was studied. To check the influence of peptides on eukaryotic cells. Human T-leukemia Jurkat cells, and human carcinoma cells (HeLa) was used. Cells were obtained from the collection of R.E. Kavetsky Institute of Experimental Pathology, Oncology and Radiobiology NAS of Ukraine (Kyiv, Ukraine). Human glioblastoma U373 MG cells were kindly provided by prof. V.M. Kavsan (Institute of Molecular Biology and Genetics, NAS of Ukraine (Kyiv, Ukraine). Cells were harvested and treated for 48 hours by the TCA-extracted peptides in final concentration of $0.1 \mathrm{mg} /$ $\mathrm{ml}$. Oligopeptides were purified by gel-filtration in PBS in HPLC condition. The amount of living and dead cells was calculated by using trypan blue staining. Biological activity of the TCA-extracted peptides was compared with the biological activity of phosphopeptides obtained from casein of bovine milk according to [7]. Anti-microbial activity of peptides purified from blood serum of MS patients was estimated toward Staphylococcus aureus, Klebsiella pneumoniae, Escherichia coli, Pseudomonas aeruginosa, Proteus spp., Candida albicans, Aspergillus fumigatus, Aspergillus niger using disk-diffusion method [8].

Statistical significance was assessed by Student's $t$-test. Three levels of significance were used ${ }^{*}-p<0.05 ;{ }^{* *}-p<0.01 ;{ }^{* * *}-p<0.001$.

\section{RESULTS AND DISCUSSION}

In order to isolate peptides from blood serum of MS patients the scheme was developed for their purification including extraction of peptides from blood serum with 
$10 \%$ trichloroacetic acid followed by precipitation of soluble compounds with acetone. To estimate concentration of specific oligopeptides in water-soluble fractions, they were filtered through Amicon 30 filter followed by determination of optical density at $280 \mathrm{~nm}$ $\left(\mathrm{OD}_{280}\right)$. The fractions with $\mathrm{OD}_{280}>0.1$ were used for investigation. As a control, $6 \mathrm{spe}-$ cies isolated in this way from blood serum of healthy donors were used. Since the $\mathrm{OD}_{280}$ of these species were lower of the determined threshold, they were not used in further study. TCA-extracted preparations with $\mathrm{OD}_{280}<0.1$ were subjected to gel filtration at HPLC condition (Fig. 1).

Fig. 1. Separation of TCA-extracted proteins isolated from blood serum of MS patient by gel-filtration on Bio-Sil SEC 250 Column in PBS (pH 6.8). F1, F2 the collected chromatographic fractions

Рис. 1. Гель-фрільтрація білкової фракції, виділеної зі сироватки крові хворих на РС за допомогою ТХO на колонці ВіоSil SEC 250 y PBS (pH 6,8). F1, F2 - зібрані хроматографрічні фракції

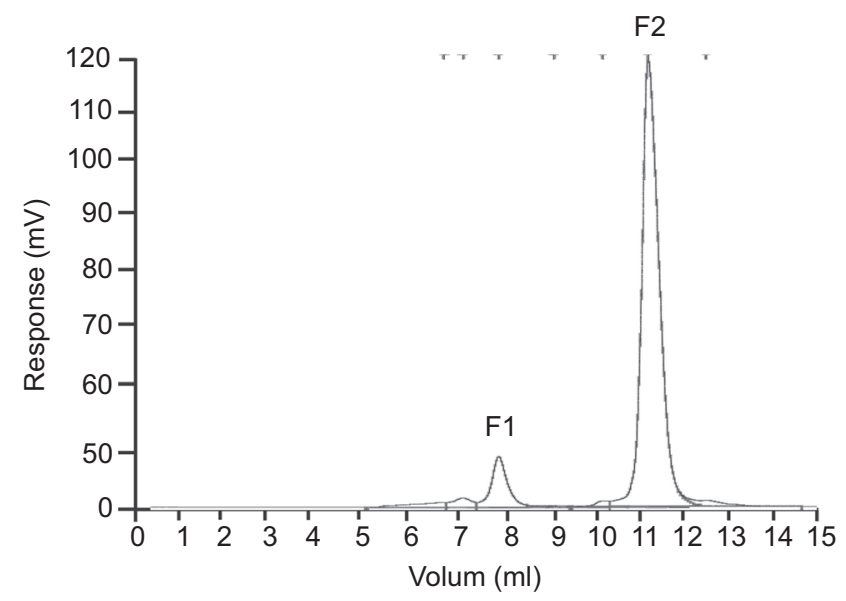

Two chromatographic fractions of compounds absorbing at $280 \mathrm{~nm}$ with molecular mass of 66 and $0.3-0.5 \mathrm{kDa}$ were isolated. Electrophoretic analysis under denaturing condition showed that polypeptide with $66 \mathrm{kDa}$ correspond to blood serum albumin (Fig. 2, lanes 1, 2), while low-molecular mass oligopeptides were not stained with Coomassie G250. It is known that the phosphopeptides of bovine casein possess cytotoxic activity toward different tumor cells [9]. That is why we compared their activity with activity of oligopeptides purified from blood serum of MS patients. The results of SDSelectrophoresis demonstrated (Fig. 2) that oligopeptides isolated from blood serum of MS patients were not stained by Coomassie, while the phosphopeptides obtained by digestion of a bovine casein in the presence of chymotrypsin, pancreatin and trypsin (Fig. 2, lanes 3, 4, 5 correspondingly) were detected as the Coomassie-stained bands with molecular mass in 3-20 kDa range.

To separate TCA-soluble peptides from blood serum of MS patients, thin-layer chromatography on silica gel plates was used. It was found that TCA-soluble peptides were present as two ninhydrin-stained chromatographic fractions with Rf of 0.79 and 0.69 (Fig. 3).

The obtained data demonstrate that blood serum of MS patients contains two oligopeptides with molecular mass 300-500 Da. Short peptides with antimicrobial and/or cytotoxic activities are presented in blood serum as an important component of immune defense [12]. We studied the biological activity of TCA-soluble peptides toward eukaryotic and prokaryotic cells. In first case, we checked their effect towards human leukemia, carcinoma and glioblastoma cells in vitro (Fig. 4).

ISSN 1996-4536 (print) • ISSN 2311-0783 (on-line) • Біологічні Студії / Studia Biologica • 2015 • Том 9/№2 • C. 51-58 

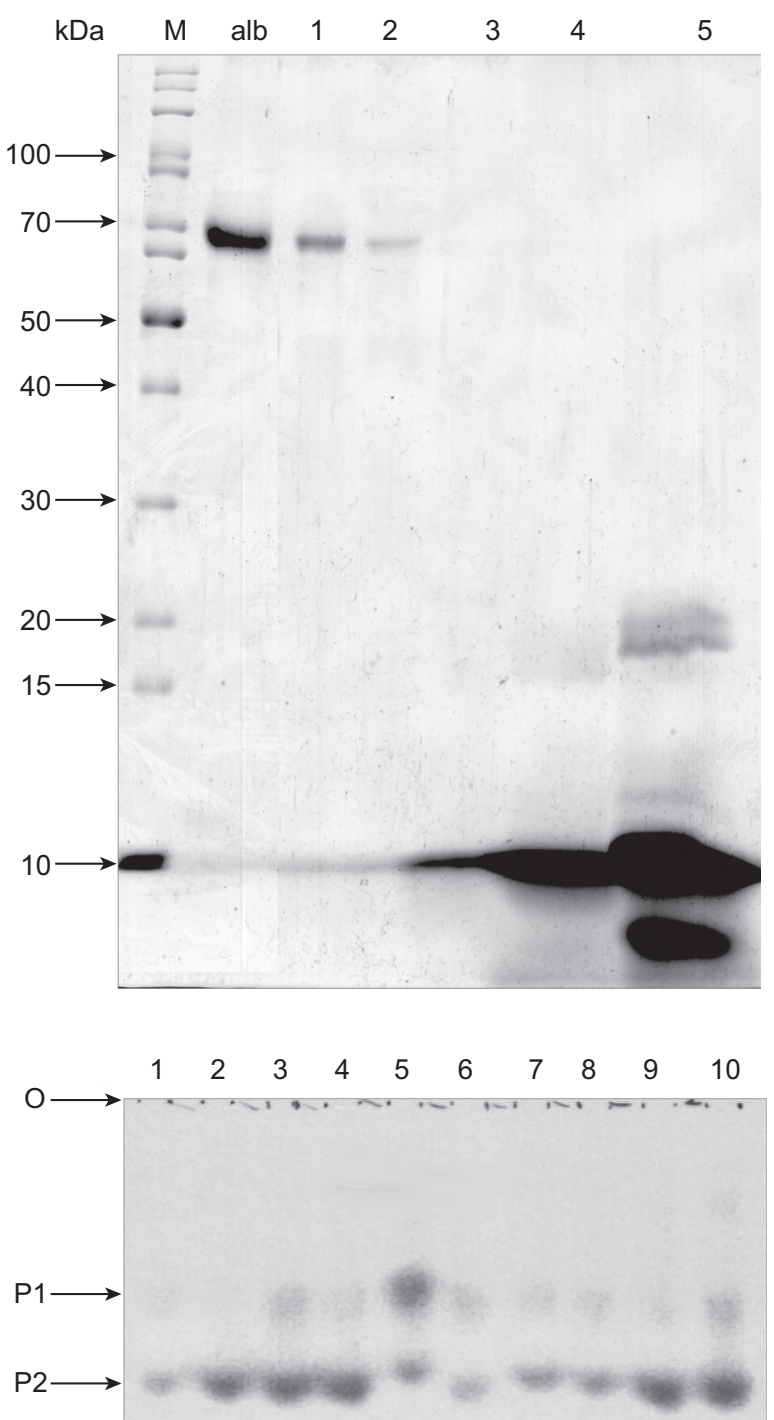

Fig. 2. Results of SDS-electrophoresis in $15 \%$ PAG of proteins isolated from blood serum of multiple sclerosis patients (lanes 1, 2), and of peptides obtained by digestion of bovine milk casein with chymotrypsin (Pep M1), pancreatin (Pep M2) and trypsin (Pep M3), respectively. Proteins on gel were stained with Coomassie G 250

Рис. 2. Результати SDS-електрофорезу в $15 \%$ ПАГ білкових фрракцій, виділених зі сироваток крові хворих на PC (доріжки 1 і 2) і пептидів, отриманих гідролізом коров'ячого казеїну за допомогою хімотрипсину (Рер M1), панкреатину (Рер M2) і трипсину (Рер М3). Білки на гелі зафрарбовано Coomassie G 250

Fig. 3. Results of thin-layer chromatography on silicagel plates in a n-butacetic acid-water $(4: 1: 1)$ of peptides isolated from blood serum of MS patient. Lanes 1-10 the samples of peptides. P1, P2 - peptides with $R_{f}$ 0.78 , and 0.69 , correspondingly

Рис. 3. Результати тонкошарової хроматографії пептидів, виділених зі сироватки крові хворих на РС. Хроматографія проводилась у системі бутанол: оцтова кислота: вода у співвідношенні 4:1:1. Доріжки 1-10 відповідають зразкам пептидів. Р1, P2 - виявлені пептиди із $R_{f} 0,78$ і 0,69, відповідно 


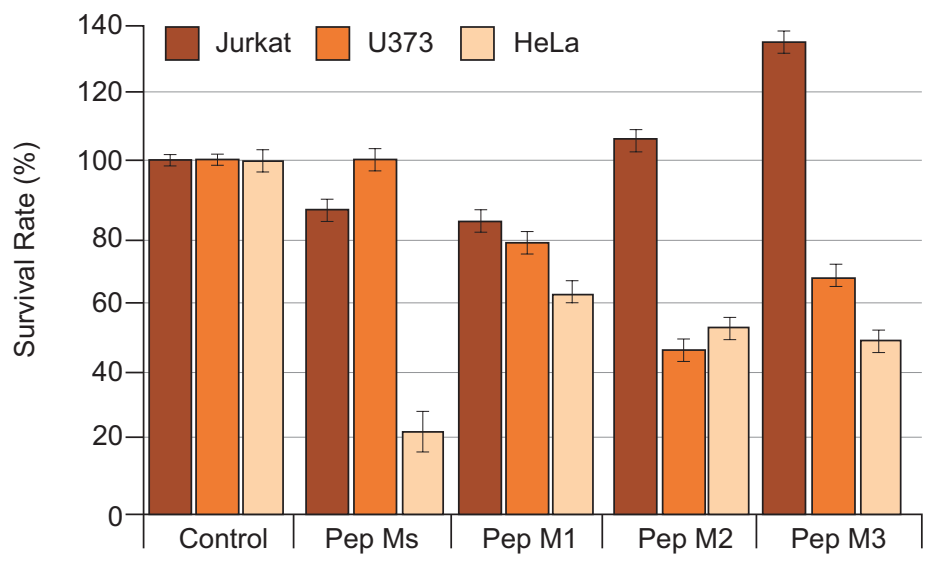

Fig. 4. Effect of peptides isolated from blood serum of MS patients and effect of bovine milk phosphopeptides on survival of tumor cells in vitro. Pep Ms - peptides purified from blood serum of MS patients. Pep M1; Pep M2; Pep M3 - phospopeptides obtained from bovine milk casein by digestion with chymotrypsin, pancreatin and trypsin respectively. Jurkat - human T-leukemia cells; U373 - human glioblastoma cells; HeLa - human carcinoma cells

Рис. 4. Вплив пептидів, ізольованих зі сироватки крові хворих на РС, і вплив фосфопептидів, отриманих гідролізом коров'ячого казеїну молока, на життєздатність клітин in vitro. Рер Ms - пептиди, виділені зі сироватки крові хворих на РС. Рер М1; Рер М2; Рер М3 - фосфопептиди, отримані гідролізом казеїну за допомогою хімотрипсину, панкреатину і трипсину, відповідно. Jurkat - лінія клітин людського Т-лейкозу; U373 - клітини людської гліобластоми; HeLa - клітини людської карциноми

It was found that TCA-soluble peptides are capable of effective inhibiting proliferation of HeLa cells while their inhibitory effect was low towards Jurkat cells and not detectable toward U373 cells. Interestingly, different species of phosphopeptides isolated from bovine milk also possessed activity towards different tumor cells in vitro (Fig. 4). Thus, the peptides obtained by hydrolysis of bovine milk with chymotrypsin possessed low inhibitory activity towards three types of target cells. In contrast, the peptides obtained by hydrolysis of bovine casein with pancreatin and trypsin were capable of stimulating proliferation of Jurkat cells and inhibited growth of U373 and HeLa cells. In other experiment, we checked the effect of TCA-soluble peptides from blood serum of MS patients towards bacteria ( $S$. aureus, K. pneumoniae, E. coli, P. aeruginosa, Proteus spp.) and fungi ( $C$. albicans, $A$. fumigatus and $A$. niger) using agar-diffusion method [8]. Neither antibacterial nor antifungal activities of these peptides were detected (data are not presented).

A reliable correlation between the concentration of peptides in serum and clinical manifestations of the disease was found. A direct correlation between the concentration of peptides and the total number of relapses in patients aged 20-40 years and patients with minimal symptoms of disability (disability score on a scale EDSS < 3) was also demonstrated. In addition, high level of peptides correlated with a relapse of MS, while low level - with a remission. These results support the hypothesis that during a relapse of the disease, a significant number of cells are destroyed and the products of that get in the peripheral blood. Such correlation was observed only in patients with a total number of relapses $\leq 5$. Probably, prolonged disease and considerable number of relapses led to changes in the degeneration process in central nervous system during a relapsing

ISSN 1996-4536 (print) • ISSN 2311-0783 (on-line) • Біологічні Студії / Studia Biologica • 2015 • Том 9/№2 • С. 51-58 
period until stable state [2]. It was found that MS relapsing progressively damaged the $\mathrm{BBB}$ and vascular permeability increased [1]. Consequently, the penetration of products of degradation through the BBB in the peripheral blood took place independent on relapses and remissions of the disease.

On the other hand, it cannot be excluded that revealed oligopeptides have another origin and are linked to degradation of blood serum proteins. We believe that massspectrometry of these oligopeptides will clarify this question.

\section{CONCLUSION}

Blood serum of the MS patients contains low-molecular mass oligopeptides with specific biological activity (inhibition of proliferation) towards specific human cells. Identification of the origin of detected oligopeptides, as well as evaluation of their biological activity are in progress.

1. Claudio L., Raine C.S., Brosnan C.F. Evidence of persistent blood-brain barrier abnormalities in chronic-progressive multiple sclerosis. Acta Neuropathol, 1995; 90: 228-238.

2. Frischer J.M., Bramow S., Dal-Bianco A. et al. The relation between inflammation and neurodegeneration in multiple sclerosis brains. Brain, 2009, 132: 1175-1189.

3. Galoyan $A$. Neurochemistry of brain neuroendocrine immune system: signal molecules. Neurochem. Res, 2000; 25(9-10): 1343-1355.

4. Hohlfeld R., Wekerle H. Immunological update on multiple sclerosis. Curr. Opin. Neurol, 2001; 14: 299.

5. Jukalo V.G., Storozh L.A. Isolation of phosphopeptides from total casein fractions. Food Chemistry and Technology, 2013; 47(2): 32-40. (In Russian).

6. Laemmli U. K. Cleavage of structural proteins during the assembly of the head of bacteriophage T4. Nature, 1970; 227: 680-685

7. Lefranc D., Almeras L., Dubucquoi S. et al. Distortion of the Self-Reactive IgG Antibody Repertoire in Multiple Sclerosis as a New Diagnostic Tool. J. Immunol, 2004; 172: 669-678.

8. Methods for the determination of susceptibility of bacteria to antimicrobial agents. EUCAST Definitive document. Clin. Microbiol. Infect, 1998; 4: 291-296.

9. Pepe G., Tenore G.C., Mastrocinque R. et al. Potential Anticarcinogenic Peptides from Bovine Milk. J. Amino Acids, 2013; 2013: 1-7.

10. Spelenberg B., Prasad S., Cabellos S. et al. Penetration of the blood-brain-barrier: enhancement of drug delivery and imaging by bacterial glycopeptides. J. Exp. Med, 1995; 182(4): 1037-1043.

11. Weinshenker B.C. Epidemiology of multiple sclerosis. Neurol. Clin, 1996; 14: 291-308.

12. Hancock R.E., Sahl H.G. Antimicrobial and host-defense peptides as new anti-infective therapeutic strategies. Nat. Biotech, 2006, 24: 1551-1557.

ISSN 1996-4536 (print) • ISSN 2311-0783 (on-line) • Біологічні Студії / Studia Biologica • 2015 • Том 9/№2 • C. 51-58 


\section{ВИДІЛЕННЯ ТА ХАРАКТЕРИСТИКА ПЕПТИДІВ СИРОВАТКИ КРОВІ ХВОРИХ НА РОЗСІЯНИЙ СКЛЕРОЗ}

С. Мироновський', Н. Негрич², Т. Негрич², М. Старикович ${ }^{1}$, В. Ткаченко1,

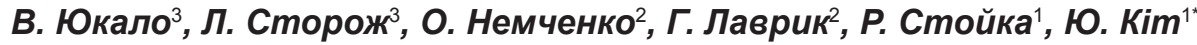

1/нститут біології клітини НАН України, вул. Драгоманова, 14/16, Львів 79005, Україна

${ }^{2}$ Львівський національний медичний університет ім. Данила Галицького вул. Пекарська, 69, Львів 79010, Україна

${ }^{3}$ Тернопільський національний технічний університет ім. Івана Пулюя вул. Руська, 56, Тернопіль 46001, Україна

*e-mail: kit@cellbiol.Iviv.ua

3 метою пошуку нових маркерів захворювання було проведено дослідження вмісту в сироватці крові хворих на розсіяний склероз (РС) олігопептидів. Для аналізу було використано 61 зразок сироватки крові пацієнтів чоловічої та жіночої статі різного віку і з різним ступенем розвитку захворювання. Білки сироватки крові осаджували трихлороцтовою кислотою (ТХO) у фінальній концентрації 10 \%. Олігопептиди осаджували із ТХО-розчинної фракції додаванням ацетону у співвідношенні 6:1. Осад розчиняли у дистильованій воді, олігопептиди аналізували тонкошаровою хроматографією (ТШХ) та гель-фрільтрацією за умов високоефективної рідинної хроматографії (BPX). Виявлено, що сироватка крові пацієнтів із РС містить два олігопептиди, які за даними ТШХ і ВРХ мають молекулярну масу 300-500 Да. Встановлено, що очищені олігопептиди сироватки крові пацієнтів із РС ефективно пригнічують ріст клітин лінії HeLa, слабо інгібують ріст клітин лінії Jurkat і не впливають на клітини лінії U373. Фосфопептиди із казеїну стимулюють проліферацію клітин лінії Jurkat i ефрективно пригнічують ріст клітин лінії U373 та HeLa. Також встановлено, що олігопептиди не впливають на ріст бактерій і грибів.

Ключові слова: олігопептиди, сироватка крові, коров'ячий казеїн, розсіяний склероз, пухлинні клітини, мікробні клітини.

\section{ВЫДЕЛЕНИЕ И ХАРАКТЕРИСТИКА ПЕПТИДОВ СИВОРОТКИ КРОВИ БОЛЬНЫХ РАССЕЯННЫМ СКЛЕРОЗОМ}

С. Мироновский ${ }^{1}$, Н. Негрич², Т. Негрич ${ }^{2}$, М. Старикович ${ }^{1}$, В. Ткаченко ${ }^{1}$, В. Юкало ${ }^{3}$, Л. Сторож, О. Немченко ${ }^{2}$, Г. Лаврик ${ }^{2}$, Р. Стойка', Ю. Кит ${ }^{1 *}$ ${ }^{1}$ Институт биологии клетки НАН Украины, ул. Драгоманова, 14/16, Львов 79005, Украина

${ }^{2}$ Львовский национальный медицинский университет им. Даниила Галицкого ул. Пекарская, 69, Львов 79010, Украина

${ }^{3}$ Тернопольский национальный технический университет им. Ивана Пулюя ул. Руська, 56, Тернополь 46001, Украина *e-mail: kit@cellbiol.Iviv.ua

С целью поиска новых маркеров заболевания было проведено исследование содержания в сыворотке крови больных рассеянным склерозом (РС) олигопептидов. Для анализа был использован 61 образец сыворотки крови пациентов мужского и женского пола разного возраста и с разной степенью развития заболева-

ISSN 1996-4536 (print) • ISSN 2311-0783 (on-line) • Біологічні Студії / Studia Biologica • 2015 • Том 9/№2 • С. 51-58 
ния. Белки сыворотки крови осаждали трихлоруксусной кислотой (ТХУ) с финальной концентрацией в $10 \%$. Олигопептиды осаждали с ТХУ-растворимой фрракции добавлением ацетона в соотношении 6:1. Осадок растворяли в дистиллированной воде и олигопептиды анализировали тонкослойной хроматографией (TCX) и гельфрильтрацией в условиях высокоэффрективной жидкостной хроматографрии (ВЖХ). Обнаружено, что сыворотка крови пациентов с РС содержит два олигопептида, которые по данным ТCX и ВЖХ имеют молекулярную массу 300-500 Да. Показано, что очищенные олигопептиды сыворотки крови больных РС подавляют рост клеток линии HeLa, слабо подавляют рост клеток линии Jurkat и не влияют на жизнедеятельность клеток линии U373. Фосфопептиды из казеина стимулируют пролиферацию клеток линии Jurkat и подавляют пролиферацию клеток линий U373 и HeLa. Также показано, что олигопептиды не влияют на рост бактерий и дрожжей.

Ключевые слова: олигопептиды, сыворотка крови, коровий казеин, рассеянный склероз, опухолевые клетки, микробные клетки.

Одержано: 08.05.2015 